\title{
LA INSTITUCIÓN DEL REFERÉNDUM EN EL DERECHO CONSTITUCIONAL EUROPEO: UN ESTUDIO COMPARADO
}

\section{THE INSTITUTION OF REFERENDUM IN EUROPEAN CONSTUTIONAL LAW: A COMPARATIVE STUDY}

\section{Pablo José Terol Orozco}

Universidad Pablo de Olavide

pjterolorozco@gmail.com

Recibido: noviembre de 2018

Aceptado: diciembre de 2018

Palabras clave: Referéndum, Derecho europeo, Derecho español, Constitución, Democracia directa Keywords: Referendum, European Law, Spanish Law, Constitution, Direct Democracy

Resumen: el Referéndum es una de las instituciones de democracia directa con mayor tradición en el constitucionalismo occidental. Este artículo pretende plantear un estudio comparado de las distintas regulaciones actuales del Referéndum en los Estados europeos, así como su papel en el Derecho español. Se concluirá el texto sintetizando algunas reflexiones doctrinales respecto de la situación del Referéndum en el constitucionalismo español del siglo XXI, exponiendo los principales argumentos a favor y en contra.

Abstract: the Referendum stands as one of the most traditional institutions of direct democracy in western constitutionalism. This article aims to lay out a comparative study on how that institution is nowadays regulated in european States, as well as its role in Spanish law. This text shall conclude with a summary of the doctrine on how the institution of Referendum fares in 21st century constitutionalism in Spain, showcasing the main arguments both in favor of and against it.

\section{Presentación}

Según la Real Academia Española de la Lengua el término Referéndum significa, en sus orígenes del latín, "lo que ha de ser consultado". Desde esta perspectiva, se puede afirmar que el contenido esencial de dicha institución apenas ha variado desde sus orígenes: se trata de proponerle una cuestión al pueblo, de plantear una pregunta. Podemos definirlo como aquel procedimiento por el que el conjunto de los ciudadanos se 
pronuncia directamente sobre una cuestión de gobierno ${ }^{1}$. En definitiva, la función del Referéndum es poner de manifiesto qué es lo que quiere la población, titular soberana del poder constituyente en las Constituciones de los modernos Estados Democráticos.

El Referéndum, dice Luis Aguiar de Luque, ha ocupado un "papel estelar" a lo largo del proceso de gestación e incorporación de la participación directa en los Estados constitucionales representativos. También afirma el profesor Aguiar que es la que mayores desconfianzas y reparos ha provocado por la fuerza material de sus resultados ${ }^{2}$. Y estas críticas, lejos de amainar, pueden tener ahora más vigencia que nunca. Hemos asistido, durante los últimos años, a numerosos episodios donde las consultas populares son empleadas como herramienta política decisiva en momentos históricos recientes de tal calado a nivel global y nacional, tales como la salida de Gran Bretaña de la Unión Europea o el proceso secesionista de Cataluña. ¿Tiene sentido dejar asuntos tan importantes en manos de una población que parece cada vez más vulnerable a la manipulación por parte de los medios y las redes? ¿Es el Referéndum en sí mismo un instrumento arcaico, primitivo, que debe ser olvidado?

El siguiente trabajo pretende dar respuesta a estas cuestiones, como un estudio de la institución del Referéndum y su posi-

1. Oliver Araujo, Joan: "El referéndum en el sistema constitucional español". Revista de Derecho Politico, n²9, 1989, p. 123.

2. Aguiar de Luque, Luis (colaborador): "Democracia directa e instituciones de democracia directa en el ordenamiento constitucional español". La experiencia constitucional, Centro de Estudios Políticos y Constitucionales, Madrid, 2000, p. 77. ción en el actual escenario jurídico y político; poniendo un particular interés en el escenario nacional, sin que ello implique dejar de lado una perspectiva comparativa del uso global de este instrumento. Queremos, con ello, plantear dos preguntas básicas: primero, por qué existe el Referéndum, la institución en sí misma; y, una vez contestada la anterior, es nuestra intención afrontar el debate sobre si dicha existencia continúa siendo necesaria en los Estados modernos.

\section{El referéndum en las Constituciones de posquerra: una experiencia comparada}

Aunque la palabra Referéndum no se introduce en el lenguaje jurídico de nuestro país hasta tiempos relativamente recientes, sus orígenes se retrotraen a los parlamentos medievales, particularmente los suizos. El término refería aquella técnica a través de la cual los representantes de los territorios, cuando sobre un tema carecían de instrucciones concretas, no tomaban sus decisiones en firme sino ad referendum, es decir, "refiriendo el asunto a sus mandantes» ${ }^{3}$.

Durante el constitucionalismo moderno, y en especial del siglo XX, veremos asentarse el uso del término "Referéndum" para referirse a aquellas consultas populares en las cuales el pueblo participa directamente en las decisiones de las instituciones políticas y, particularmente, del poder legislativo ${ }^{4}$.

3. Oliver Araujo, Joan: "El referéndum en el sistema constitucional español". Op. cit., p. 122.

4. El uso de la palabra "Referéndum" se extiende, además, en contraposición al del término "plebiscito", el cual tiene asociadas connotaciones más 


\section{I Participación directa en el constitucionalismo helvético}

El Estado suizo siempre ha sido uno de los referentes por excelencia en cuanto a democracia directa, y a cómo esta puede complementar y completar la democracia representativa: se afirma que su historia constitucional se define por la profundización y ampliación de la democracia directa. Ya en la (ahora derogada) Constitución de 1874 venía previsto un avanzado desarrollo de diversas formas de participación en forma de Referéndum e iniciativa popular, tanto a nivel cantonal como federal; disposiciones se continúan ampliando a través de reformas constitucionales, incluso extendiendo su ámbito a la aprobación de Tratados internacionales, como se hizo en las reformas de 1921 y $1977^{5}$.

El actual texto constitucional, aprobado en Referéndum el 18 de abril de 1999, destacaría por ampliar y renovar especialmente su catálogo de Derechos Fundamentales, inspirándose en el Derecho internacional, la Convención Europea de Derechos Humanos y la jurisprudencia del Tribunal Europeo de Derechos Huma-

negativas en el constitucionalismo histórico europeo por verse vinculado, como veremos más adelante, a aquellas consultas populares que se emplearon deshonestamente para legitimar poderes dictatoriales conquistados mediante el uso de las armas: entre ellos, el régimen bonapartista francés o la dictadura franquista en España. Aunque en los últimos años, afirma el profesor Oliver Araujo, existe la tendencia de equiparar ambos términos, Referéndum y plebiscito, desproveyendo a este último de su tradicional connotación peyorativa.

5. Sáenz Royo, Eva: "La regulación y la práctica del referéndum en Suiza: un análisis desde las críticas a la institución del referéndum." Revista de Estudios Políticos, no 171, 2016, p. 75. nos; reconociendo, a su vez, la primacía del mentado Derecho internacional sobre el interno, tanto federal como cantonal ${ }^{6}$.

Resulta reseñable que el Derecho de participación como Derecho Fundamental solo viene recogido en la Constitución de 1999 en la medida en que esta regula los mecanismos participativos; debe entenderse que el reconocimiento de este derecho viene dado, no solo por la relevancia de la costumbre participativa en Suiza, sino también por remisión a la supremacía del Derecho internacional y los Tratados referentes a los Derechos Humanos donde sí viene regulada la participación, como pueden ser la Declaración Universal de 1948 .

Dos son los instrumentos participativos que recoge el texto constitucional helvético: la iniciativa popular y el Referéndum. La iniciativa popular permite que el pueblo pueda intervenir en la agenda política e introducir nuevas cuestiones, mientras que el Referéndum ofrece a los electores la oportunidad de pronunciarse sobre proyectos legislativos o decisiones políticas. No son herramientas aisladas sino que están profundamente ligadas entre sí: la iniciativa legislativa popular, en Suiza, se concibe mayormente como iniciadora del proceso de reforma Constitucional y, por tanto, debe eventualmente verse sometida a Referéndum. Es decir, que ambas instituciones pueden actuar entrelazadas,

6. Koller, Heinrich, \& Biagnni, Giovanni: "La nueva Constitución Federal Suiza. Una visión General de las novedades y los aspectos más destacados". Teoría y Realidad constitucional, nº11, 2002, pp. 611-634.

7. Soto Barrientos, Francisco: "La democracia como forma de Estado: Análisis de los mecanismos de participación directa en la Constitución Suiza". Estudios Constitucionales, vol. 10 n 1 , 2012, p. 375. 
una como consecuencia de la otra; en la práctica, la iniciativa popular existe para someter a Referéndum una propuesta de reforma constitucional ${ }^{8}$.

Según el artículo 140 de la Constitución Federal, las siguientes materias deben ser obligatoriamente sometidas a Referéndum: las revisiones de la Constitución; la adhesión a organizaciones de seguridad colectiva o a las comunidades supranacionales; las leyes federales declaradas urgentes, que estén desprovistas de base constitucional y que la duración de su validez sea superior al año; las iniciativas populares que tengan como objeto la revisión total de la Constitución; las iniciativas populares concebidas en términos generales que tengan como objeto la revisión parcial de la Constitución y que hayan sido rechazadas por la Asamblea Federal; el principio de una revisión total de la Constitución, en caso de desacuerdo entre ambos Consejos ${ }^{9}$.

De todas estas consultas, unas deben ser sometidas al voto del pueblo y los cantones (revisión de la Constitución, adhesión a organizaciones de seguridad colectiva o comunidades supranacionales, y ratificación de las leyes federales declaradas vigentes que estén desprovistas de base constitucional y cuya duración supere un año desde su aprobación); y otro sólo al pueblo (las iniciativas populares para la reforma total de la Constitución, las iniciativas populares generales rechazadas por la Asamblea Federal, y la cuestión de si

8. Sáenz Royo, Eva: "La regulación y la práctica del referéndum en Suiza: un análisis desde las críticas a la institución del referéndum." $O p$. cit., p. 74.

9. Sáenz Royo, Eva: "La regulación y la práctica del referéndum en Suiza: un análisis desde las críticas a la institución del referéndum." $O p$. cit., p. 77. se debe llevar a cabo una reforma total de la Constitución en caso de desacuerdo entre los dos Consejos). En cuanto al Referéndum facultativo, se establece esta posibilidad para las decisiones federales de carácter urgente, esto es, leyes y disposiciones federales. La iniciativa corresponde también a la propuesta ciudadana, estableciendo como requisito el que se cuente con el apoyo de 50.000 ciudadanos con derecho a voto, u ocho cantones. La ratificación de un Tratado internacional, o de su resolución de aprobación, también puede quedar sometida a Referéndum, estando la Asamblea Federal facultada para introducir las reformas constitucionales que sean necesarias para incluir el Tratado aprobado en consulta popular ${ }^{10}$.

Al igual que ocurría en los textos anteriores, la reforma constitucional es uno de los procedimientos donde se ve más claramente la vinculación entre Referéndum e iniciativa popular en la Constitución Federal de 1999. Esta se puede llevar a cabo en dos modalidades: total o parcial. Para ambas modalidades se exige la firma de 100.000 ciudadanos con derecho a voto, que deben ser acreditadas en un plazo de 18 meses desde la publicación en el diario oficial de la solicitud de la adopción, modificación o abrogación de disposiciones constitucionales; el plazo es relativamente corto, y uno de los motivos por los que fracasan varias iniciativas es, precisamente, por no lograr reunir el elevado número de firmas requerido en el plazo impuesto. Además, la iniciativa debe cumplir tres requisitos: primero, unidad de forma, debiendo presentarse bien

10. Soto Barrientos, Francisco: "La democracia como forma de Estado: Análisis de los mecanismos de Participación directa en la Constitución Suiza”. Op. cit., pp. 390-391. 
como una proposición general o como un proyecto concreto (nunca una mezcla de ambas); segundo, unidad de materia, esto es, venir dirigida a cuestiones que estén claramente relacionadas; y tercero, ser acorde con las reglas imperativas de Derecho Internacional (ius cogens) ${ }^{11}$.

En cualquier caso, la reforma debe ser sometida a Referéndum, en el cual el voto mayoritario aprueba el proyecto; pero para las reformas no solo se exige la mayoría de los votantes, sino que también se obtenga una mayoría de Cantones, esto es, del voto popular individualizado de forma cantonal ${ }^{12}$. Es por esto por lo que muy pocas iniciativas de reforma constitucional parcial superan el proceso de aprobación en Suiza: desde 1891 solo 15 proyectos han logrado salir adelante. También debemos recalcar que la Asamblea Popular tiene la facultad, no solo de rechazar el proyecto por los motivos antes citados de unidad de forma, materia o contradicción con el Derecho internacional, sino también de presentar un contraproyecto que ha de ser igualmente sometido a consulta ${ }^{13}$.

La práctica referendaria en Suiza nos ofrece una serie de datos y conclusiones interesantes. La primera es el escaso nivel de participación ciudadana, con la media situándose por debajo del 50 por ciento. Hay que tener en cuenta que las consultas

11. Sáenz Royo, Eva "La regulación y la práctica del referéndum en Suiza: un análisis desde las críticas a la institución del referéndum." Op. cit., pp. 76-77.

12. Soto Barrientos, Francisco: "La democracia como forma de Estado: Análisis de los mecanismos de Participación directa en la Constitución Suiza". Op. cit., pp. 386-388.

13. Soto Barrientos, Francisco: "La democracia como forma de Estado: Análisis de los mecanismos de Participación directa en la Constitución Suiza”. Op. cit., pp. 388-389. pueden versar sobre materias muy diversas, y no todas generan el mismo interés público; por ejemplo, los Referéndums referidos a políticas de inmigración y mano de obra extranjera, política internacional y adhesión al Espacio Económico Europeo, y la supresión del ejército, vieron todos ellos una participación superior al 70 por ciento. Y, de hecho, los sondeos realizados entre la población suiza tienden a mostrar un elevado grado de satisfacción ciudadana para con el sistema democrático ${ }^{14}$.

El segundo dato a tener en cuenta es que las consultas populares, lejos de debilitar a los partidos políticos helvéticos, han servido para reforzarlos. Los partidos suizos no tienen reparos en recurrir a la institución referendaria, particularmente cuando se encuentran en la oposición y necesitan una herramienta que les permita oponerse a las mayorías parlamentarias. Pero estas mayorías también pueden beneficiarse de la democracia directa, como demuestra el éxito que ha tenido la potestad parlamentaria de presentar contraproyectos a las iniciativas populares, contraproyectos que encuentran su legitimidad al ser sometidos a Referéndum ${ }^{15}$. La participación funciona no solo de abajo hacia arriba, sino también en sentido contrario, y resulta lógico: una propuesta presentada por una fuerza política que haya obtenido la mayoría parlamentaria en un proceso electoral cuenta con unas garantías de éxito mayores que las de un proyecto iniciado por las minorías. Por otro lado,

14. Sáenz Royo, Eva: "La regulación y la práctica del referéndum en Suiza: un análisis desde las críticas a la institución del referéndum." $O p$. cit., p. 82-83.

15. Sáenz Royo, Eva: "La regulación y la práctica del referéndum en Suiza: un análisis desde las críticas a la institución del referéndum." $O p$. cit., p. 84-85. 
un sistema eminentemente pluripartidista como es el suizo, la posibilidad de remitir las disputas a la decisión referendaria permite resolver disensiones puntuales entre los programas de los partidos gobernantes y resolver tensiones sin tener que acudir a nuevas elecciones, mejorando la estabilidad del sistema ${ }^{16}$.

Esto tampoco quiere decir que las minorías queden completamente desprotegidas. La simple existencia de las iniciativas populares en el texto constitucional es en sí misma una medida contra el abuso de las mayorías. Y es cierto que los Referéndums implican una toma de decisiones de carácter determinante, que se decanta por una opción afirmativa o negativa sin que exista una posible negociación para acercar las posiciones; pero esto no quiere decir que la deliberación esté ausente en todo el procedimiento. Toda iniciativa ha de pasar por varias fases y espacios de deliberación antes de ser efectiva, como son la Asamblea Federal o los Parlamentos cantonales ${ }^{17}$. El sistema federalista

16. Soto Barrientos, Francisco: "La democracia como forma de Estado: Análisis de los mecanismos de Participación directa en la Constitución Suiza". Op. cit., pp. 392-397.

17. Soto Barrientos hace especial énfasis en la importancia que tiene la negociación como elemento esencial del proceso político helvético. En efecto, las fórmulas negociadoras y deliberativas se convierten en un corrector imprescindible cuando el sistema participativo no es capaz de formular acuerdos claros, por ejemplo, en aquellos casos en los que se muestre una clara división en la población. Así, Suiza se configura como una democracia de carácter marcadamente pluripartidista, donde la negociación entre los diversos agentes del poder político que participan en las instituciones es un elemento esencial de su funcionamiento rutinario. El Poder Ejecutivo en Suiza no recae sobre un Jefe de Gobierno, sino sobre un Consejo Federal cuyos consejeros son elegidos por mayoría absoluta en la Asamblea cantonal actúa también como protección de las minorías territoriales, asegurando que sus voces no puedan quedar desoídas en el proceso; aunque esto puede provocar que una reforma quede paralizada por no haber sido aceptada por el número suficiente de cantones, a pesar de obtener el voto mayoritario.

No se debe obviar que estos niveles de participación, que los autores han llegado a denominar como "democracia semidirecta", se hace posible gracias al alto nivel de organización de la sociedad helvética, acostumbrados como están a un alto nivel de participación en la vida política, y a su organización federal que permite una administración muy eficiente de cada territorio, facilitando en gran medida la labor referendaria.

\subsection{La figura del Referéndum en el constitucionalismo italiano de posquerra}

El Referéndum como instrumento participativo ha estado presente en el constitucionalismo italiano moderno desde sus inicios: el 2 de junio de 1946 se celebró un Referéndum en el cual el pueblo de Italia votó por poner fin a la tradición monárquica que venía existiendo desde 1848, y optó

Federal. Tanto la Asamblea como el Consejo reflejan ese carácter pluripartidista en un variado espectro de perspectivas políticas; por tanto, la deliberación se vuelve central en cualquier proceso de toma de decisiones. La negociación juega también un importante papel en las relaciones entre los cantones y el gobierno federal. Esta combinación de elementos deliberativos y participativos lleva al profesor Soto Barrientos a calificar a Suiza de "laboratorio democrático" cuyas experiencias han sido ejemplos a seguir por muchos otros países que aspiran a introducir la democracia participativa en sus Constituciones. 
por transformar al país en una República parlamentaria18. En la Constitución italiana, que entró en vigor el 1 de enero de 1948, están previstas hasta tres instituciones de democracia directa, que se establecen como correctoras del sistema representativo, a saber: Referéndum constitucional, legislativo e iniciativa popular.

El Referéndum constitucional fue incluido en el artículo 138: las leyes que impliquen revisión de la Constitución, tras ser aprobadas en dos deliberaciones sucesivas por cada una de las Cámaras, podrán ser sometidas a Referéndum si lo solicitan, al menos, una quinta parte de los miembros de cada una de las Cámaras, cinco consejos regionales o quinientos mil electores, en los tres meses siguientes a la publicación del texto; pero solo si la Ley en cuestión no ha alcanzado, en su segunda votación, la mayoría de dos tercios en su aprobación ${ }^{19}$. El Referéndum constitucional no había visto un uso particularmente extensivo hasta que, en 1994, la coalición de centroderecha liderada por Silvio BerIusconi presenta un amplio programa de reformas constitucionales: dado que la Constitución italiana no requiere de unas mayorías cualificadas para plantear la reforma, el Referéndum constitucional pasó a ser la principal arma de la oposición para oponerse a las reformas ${ }^{20}$.

El Referéndum legislativo se incluyó únicamente con carácter abrogatorio: podía derogar total o parcialmente leyes ya

18. Aguiar de Luque, Luis: "Democracia directa y Estado constitucional", Edersa, Madrid, 1977, p. 185.

19. Aguiar de Luque, Luis: "Democracia directa y Estado constitucional", Op.Cit.. 190-191.

20. Olivietti, Marco: "Los refrendos en serio: la experiencia italiana". Traducción de Francisco M. Ruiz-Risueño Montoya para la Universidad Autónoma de Madrid, pp. 167-168. existentes, pero no proponer ni aprobar nuevos textos. También facultativo, podía ser iniciado a instancia de cinco consejos electorales o de quinientos mil electores (se excluía la iniciativa por parte de las Cámaras por su evidente potencial para acabar suponiendo un obstáculo al ordinario funcionamiento del sistema parlamentario). El artículo 75 excluye de este referéndum las leyes tributarias y de presupuesto, de amnistía e indulto o de ratificación de tratados internacionales. Y para que los resultados sean considerados válidos se exige una participación de al menos el 50\% del quórum electoral$^{21}$. La gran mayoría de estos refrendos han sido puestos en marcha por iniciativa popular, y la Corte Constitucional tiene competencia para pronunciarse sobre su admisibilidad; de hecho, la jurisprudencia de la Corte ha aumentado significativamente los límites de este Referéndum, prohibiendo que se pudiera plantear la abrogación de las disposiciones incluidas en la Constitución, de las leyes de revisión constitucional, y otras diversas ${ }^{22}$.

A nivel regional y local, la Constitución permite, en su artículo 123, que el Estatuto de cada región regule el ejercicio del derecho de Referéndum, aunque es una herramienta que ha tenido escasa acogida. También existe la previsión de Referéndum en el caso de creación de nuevas regiones o de fusión de regiones ya existentes, siempre que sea solicitado

21. Cuesta López, Víctor Manuel: "Participación directa e iniciativa legislativa del ciudadano en democracia constitucional". Tesis doctoral, Universidad de las Palmas de Gran Canaria, 2007., pp. 75-77.

22. Olivietti, Marco: "Los refrendos en serio: la experiencia italiana". Traducción de Francisco M. Ruiz-Risueño Montoya para la Universidad Autónoma de Madrid, pp. 152 y 159. 
por el suficiente número de representantes (un tercio) de las poblaciones representadas; aunque es siempre de carácter consultivo ${ }^{23}$. El artículo 123 prevé, además, un Referéndum para la ratificación de los estatutos regionales, dentro de los tres meses a contar desde su publicación y a iniciativa de $1 / 50$ de los electores o a iniciativa de $1 / 5$ de los componentes del Consejo Regional24.

La regulación del Referéndum en Italia viene contenida principalmente en la Ley de 25 de mayo de 1970. Respecto de este texto legislativo, llama la atención la escasa referencia a la participación de los partidos políticos en la campaña referendaria, y el extremado número de cautelas que se adoptan en torno a la recogida de firmas, la comprobación de su veracidad, y otros aspectos de la campaña (cautelas por otra parte comprensibles, teniendo en cuenta la experiencia de Weimar y el hecho de que Italia venía recién salida de una dictadura fascista ${ }^{25}$.

Desde la entrada en vigor de esta Ley, el Referéndum se empleó en Italia en varias ocasiones, destacando especialmente las consultas respecto a las leyes sobre el divorcio, donde la población italiana se manifestó claramente a favor de esta institución legal, pese a la gran influencia del partido democristiano. Dice sin embargo Luis Aguiar que "las instituciones de participación directa en la República Italiana han desempeñado un papel accesorio y

23. Aguiar de Luque, Luis: "Democracia directa y Estado constitucional”, Op. cit., pp. 196-197.

24. Cuesta López, Víctor Manuel: "Participación directa e iniciativa legislativa del ciudadano en democracia constitucional". Op. cit., pp. 75-79.

25. Aguiar de Luque, Luis: "Democracia directa y Estado constitucional”, Op. cit., pp. 200-203. complementario de un régimen básicamente parlamentario" 26 .

\subsection{El Referéndum en la Constitución Francesa de 1958}

Aprobada también por vía referendaria, la $\checkmark$ República Francesa adoptará un régimen denominado como "semipresidencial", y recogerá en su Constitución tres variantes de Referéndum: constitucional, legislativo y local.

El artículo 3 de la Constitución establece que "la Soberanía Nacional pertenece al pueblo, que la ejerce por sus representantes o por la vía del Referéndum". El artículo 86, parcialmente derogado, establece el Referéndum local, y tiene por objeto la transformación del Estatuto de un Estado miembro de la comunidad. El artículo 11 otorga al Presidente de la República la facultad de someter a Referéndum, a propuesta del Gobierno, todo proyecto de Ley referente a la organización de los poderes públicos que comporte la aprobación de un acuerdo de comunidad o la ratificación de un tratado que incida en el funcionamiento de las instituciones. Finalmente, el artículo 89 establece el Referéndum como medio de aprobar las reformas constitucionales, a no ser que estas hayan sido aprobadas en las Cámaras, reunidas conjuntamente, con una mayoría de 3/527.

El Referéndum vería un uso bastante continuado en la República francesa a lo largo del siglo XX. De especial relevancia

26. Aguiar de Luque, Luis: "Democracia directa y Estado constitucional", Op. cit., pp. 204.

27. Aguiar de Luque, Luis: "Democracia directa y Estado constitucional”, Op. cit., pp. 157-158 y 166-176. 
sería la consulta convocada en 1962 por el general Charles de Gaulle, a partir de la cual se estableció que el Presidente de la República debería ser elegido por sufragio universal: una consulta que difuminó los límites entre los distintos refrendos previstos en los artículos 11 y 89, aunque sus resultados terminaron por constitucionalizar de forma indiscutible el nuevo mecanismo de elección presidencial. El Referéndum volvería a ser utilizado en 1968, 1969 y 1972; salvo en este último, la participación popular en las consultas referendarias se mantuvo siempre por encima del 70 por ciento. La historia del Referéndum en Francia se vio, sin embargo, constantemente mancillada por las vicisitudes políticas que pasó el país en aquellos años, como la cuestión del derecho de autodeterminación de Argelia, tradicional colonia francesa. De Gaulle, primer Presidente de la República, trató sistemáticamente de utilizar el Referéndum como una herramienta para aumentar sus poderes en detrimento de las instituciones parlamentarias. De Gaulle empleó de este modo el Referéndum como un instrumento que reforzara los poderes del Presidente frente a las Cámaras asamblearias, y la marca gaullista no ha dejado de notarse en los posteriores Referéndums que se han celebrado en Francia mucho tiempo después de su retiro ${ }^{28}$.

\subsection{El Referéndum en Gran Bretaña}

En la historia reciente de Gran Bretaña, monarquía parlamentaria que se caracteriza por su carencia de una Constitución escrita, destacaremos dos casos parti-

28. Aguiar de Luque, Luis: "Democracia directa y Estado constitucional”, Op. cit., pp. 159-161. culares en los cuales la figura del Referéndum se empleó para decidir sobre cuestiones determinantes para el futuro del país: el Referéndum de 5 de junio de 1975, sobre la permanencia de Gran Bretaña en la Comunidad Económica Europea; y su contraparte, el Referéndum de 23 de junio de 2016 sobre la salida de Gran Bretaña de la Unión Europea, más popularmente conocido como "Brexit".

Aunque el Estado británico había entrado en la CEE en 1973, su permanencia continuó siendo objeto de fuertes debates hasta la votación del 75, y todavía en los años venideros seguiría suscitando la polémica. En efecto, y por irónico que resulte, Reino Unido se "casa" y se "divorcia" de Europa mediante sendas consultas populares, ambas irremediablemente vinculadas al contexto político de sus respectivos momentos históricos. En el caso del Referéndum de 1975, podemos vincularlo a dos grandes crisis: por un lado, la división interna del entonces gobernante Partido Laborista; por otro, la crisis del propio régimen parlamentario británico.

En 1974, el Partido Laborista se encontraba con una difícil situación en torno a la cuestión de la incorporación de Gran Bretaña a la CEE, a pesar de su victoria en las elecciones generales de octubre (gracias, en gran parte, a la promesa de solventar definitivamente la cuestión europea); viéndose escindido entre los miembros del partido a favor de la adhesión y aquellos en contra de la misma. La única solución práctica a este problema pasaba por llevar a cabo una consulta popular y dejar la decisión en manos del pueblo. Al mismo tiempo, debemos tomar en consideración los problemas que enfrentaba el sistema político británico, un régimen parlamentarista basado en un bipartidismo estricto con alternancias regulares en el poder de 
las dos fuerzas políticas mayoritarias: a los partidos les cuesta cada vez más obtener esa mayoría decisiva que les garantizaba un gobierno estable, al mismo tiempo que deben lidiar con sus propias crisis internas. El Referéndum se postula así como la alternativa a un Parlamento demasiado debilitado para tomar una decisión firme e incuestionable con respecto al asunto europeo ${ }^{29}$.

La celebración del Referéndum por si sola ya ponía en jaque los pilares del purista régimen parlamentario que imperaba en Reino Unido. La soberanía en Gran Bretaña no descansa en el pueblo, sino en el Parlamento, y solo a través de la elección de sus representantes puede el pueblo británico participar en la vida política. Pero el Referéndum del 75 supuso una ruptura radical con todo lo que esto significaba. Los defensores de la consulta popular argumentaban que el poder del Parlamento, aunque soberano, descansa sobre el pueblo y que, en cualquier caso, el Referéndum no tenía más que un carácter consultivo. Fuera como fuese, la elevada participación en el Referéndum, junto con la abrumadora mayoría del voto afirmativo (casi un 70\% de los más de 25 millones de votantes se manifestaron a favor de la permanencia) sirvió, no solo para poner fin, por el momento, a esa disputa particular, sino también para aliviar en medida considerable las tensiones políticas en Reino Unido, y sentó un importante precedente para la aún reciente votación de $2016^{30}$.

El 23 de junio del año pasado se celebró el famoso "Brexit", con una participación

29. Aguiar de Luque, Luis: "Democracia directa y Estado constitucional”, Op. cit., pp. 218-222.

30. Aguiar de Luque, Luis: "Democracia directa y Estado constitucional”, Op. cit., pp. 223-226. muy superior a la de 1975: más de 33 millones de votantes, el $72 \%$ del cuerpo electoral. Los resultados fueron, en este caso, mucho más divisorios: alrededor del $51 \%$ votaron a favor de abandonar la Unión Europea, unos 17 millones de electores, frente a los 16 millones que votaron a favor de la permanencia. El Brexit debe ser entendido a la luz de los acontecimientos que han dado forma a los primeros años del siglo XXI: la dura crisis económica, los sangrientos ataques producidos por el terrorismo internacional, el desencanto para con las promesas de la globalización, etc.... Estos y muchos otros factores han llevado a un renacimiento general de los movimientos nacionalistas y proteccionistas por todo Occidente. El gran argumento de quienes se posicionan a favor de la salida se centra en la protección de la economía británica frente a una Unión Europea que toma más de lo que da, y una inmigración cada vez más difícil de controlar. El Referéndum del año 1975 sentó un importante precedente para el parlamentarismo inglés, y de nuevo se decidió solventar el debate mediante consulta popular (y, por segunda vez, el Partido Laborista utilizó la promesa del Referéndum como estrategia política para asegurarse el éxito electoral) ${ }^{31}$.

Como se hiciera también en el 75, algunas voces reclaman que el Referéndum, dado el principio de soberanía parlamentaria, no es vinculante para las Cámaras británicas; y ya han surgido los primeros movimientos de respuesta que exigen la celebración de una segunda votación. Los propios británicos han sufrido un cierto varapalo económico como consecuencia de su decisión; una respuesta de la que,

31. Martino, Antonio A.: "Brexit". Revista POSTData: Revista de Reflexión y Análisis Político, vol. 21 n², 2016, pp. 565-571. 
por otra parte, ya se les había advertido. Quizá, después de todo, Reino Unido no haya despertado aún de su glorioso sueño de imperio colonial. En cualquier caso, resulta sumamente interesante el papel que ha jugado una institución de democracia directa como es el Referéndum, en un régimen parlamentario tan purista como el de Reino Unido. Las consecuencias que esto tenga a largo plazo solo podremos saberlas con certeza cuando ya sea demasiado tarde para evitarlas.

\section{El referéndum en el actual ordenamiento jurídico español}

La participación del ciudadano español en el proceso político viene reconocida como un Derecho Fundamental del más alto orden en nuestra Constitución. Así lo recoge el artículo 23.1, que reza: "Los ciudadanos tienen el derecho a participar en los asuntos públicos, directamente o por medio de representantes, libremente elegidos en elecciones periódicas por sufragio universal". Este precepto se completa con el recogido en el artículo 9.2, que establece la obligación para los poderes públicos de "facilitar la participación de todos los ciudadanos en la vida política, económica, cultural y social". El profesor Cuesta López, nos advierte, sin embargo, que "estamos ante un precepto programático, de escasa operatividad, que fija un objetivo sin precisar las obligaciones que se derivan para los poderes públicos"32.

32. Cuesta López, Víctor Manuel: "Participación directa e iniciativa legislativa del ciudadano en democracia constitucional”. Op. cit., p. 83.
Nuestra Constitución es considerablemente escueta a la hora de desarrollar los instrumentos de participación directa, y el Tribunal Constitucional se ha expresado de forma contundente a la hora de delimitar los supuestos de participación directa a las distintas modalidades de Referéndum que vienen previstas a lo largo del texto constitucional (artículos 92, 149.1.32, 151.1 y 2, 167, 168 y Disposición Transitoria $4^{\mathrm{a}}$ ); llegando a afirmar que "y aun si se admitiera que la Ley puede ampliar los casos de participación directa, los supuestos habrían de ser, en todo caso, excepcionales en un régimen de democracia representativa como el instaurado por nuestra Constitución, en el que priman los mecanismos de democracia representativa sobre los de participación directa"33. El TC, en efecto, siempre se ha mostrado restrictivo a la hora de pronunciarse sobre la participación directa, y nunca ha tenido reparo en manifestar abiertamente que, en su doctrina, un Estado democrático equivale a una democracia parlamentaria $\mathrm{y}$, en el caso de los modernos Estados, a democracia de partidos ${ }^{34}$.

Lo afirma el Tribunal con claridad prístina: España se configura como un régimen representativo, y las manifestaciones de democracia directa serán siempre la excepción, nunca la norma. Debemos entender esta configuración desde el recelo que provoca la tradición plebiscitaria del régimen franquista, y la importancia que se le da, durante la transición, a fortalecer los partidos políticos como fuente de pluralidad parlamentaria, en una democracia recién nacida de las cenizas un régimen

\section{STC 119/1995, FJ $3^{\circ}$.}

34. Pérez Luño, Antonio Enrique: "Democracia directa y democracia representativa en el sistema constitucional español". Anuario de Filosofía del Derecho, n²0, 2003., pp. 75-77. 
dictatorial; partidos que, en varios casos, habían sufrido duras persecuciones ideológicas durante el franquismo y se habían visto obligados a sobrevivir en la clandestinidad. De hecho, durante el debate constituyente se llegaron a proponer hasta tres modalidades de Referéndum legislativo: suspensivo, abrogatorio y consultivo. Sin embargo, solamente esta última llegó a tener presencia en el texto final, por el miedo a las posibles manipulaciones que pudiera sufrir la consulta o a la división que podría llegar a provocar en un país que apenas había terminado de unificarse tras una difícil y delicada transición política ${ }^{35}$.

Así pues, las consultas populares previstas en la Constitución pueden agruparse en tres grupos principales: el Referéndum consultivo del artículo 92 para decisiones políticas de especial trascendencia; el Referéndum en el ámbito autonómico, para la aprobación y reforma de los Estatutos de Autonomía o la configuración de nuevas Comunidades Autónomas; y el Referéndum de reforma constitucional.

La definición del Referéndum y su distinción para con la figura de la consulta popular también ha traído cierto debate. Parte de la doctrina afirma que el Referéndum, en el proceso político, se identifica con la toma de decisiones, convocando al pueblo para que exprese su voluntad afirmativa o negativa para con aquella decisión política que se ponga en cuestión. Esta definición, sin embargo, no es compatible con nuestro marco constitucional, pues ya veremos que el artículo 92 reconoce expresamente un Referéndum de carácter meramente consultivo, cuyo objeto tiene una delimitación poco

35. Cuesta López, Víctor Manuel: "Participación directa e iniciativa legislativa del ciudadano en democracia constitucional". Op. cit., pp. 86-87. clara y genérica ("cuestiones políticas de especial trascendencia"). Ante esta disyuntiva, la definición que el Tribunal Constitucional viene a darnos del Referéndum es identificarlo como "un género especial de consulta popular" que se caracteriza por el sujeto al que se dirige, el cuerpo electoral registrado en el censo electoral; así como por las especiales garantías con las que debe realizarse el procedimiento, equivalentes, de hecho, a la de cualquier proceso electoral. Primero, porque el censo electoral se empleará de hecho como base para la consulta; y segundo, por la especial trascendencia de las cuestiones que se proponen. En cambio, una consulta popular, por exclusión, agruparía a aquellos procedimientos que pueden estar dirigidas a otros colectivos o ampliar el alcance de la consulta (por ejemplo, a menores de edad), seguir cualquier otra forma distinta de la electoral (como una encuesta) y venir referidas a cualquier aspecto de la vida pública, tenga o no trascendencia política. Afirma el Tribunal que "la circunstancia de que no sea jurídicamente vinculante resulta [...] irrelevante, pues es obvio que el referéndum no se define frente a otras consultas populares por el carácter vinculante de su resultado ${ }^{36}$.

\section{3.l. El Referéndum consultivo del artículo 92}

Adentrándonos ya en materia, el artículo 92.1 de la Constitución prevé que "las decisiones políticas de especial trascendencia podrán ser sometidas a referéndum consultivo de todos los ciudadanos". Dicho Referéndum será convocado por el Rey, a propuesta del Presidente del Go-

36. STC $103 / 2008$, FJ $^{\circ}$ y $3^{\circ}$. 
bierno, previa autorización de las Cortes Generales. Es decir, las Cámaras legislativas no pueden convocar un Referéndum, ni obligar al presidente a que haga uso de su iniciativa, pero son las que, en última instancia, se pronuncian al respecto. Como viene recogida en la Ley Orgánica de desarrollo de esta institución, que estudiaremos más adelante, se requiere la mayoría absoluta del Congreso de los Diputados (artículo 6). Esto viene a ser una medida de racionalización de la institución, para impedir su uso excesivo o con fines demagógicos por parte del Ejecutivo $^{37}$.

La redacción del artículo 92 ha sido objeto de no pocas críticas por parte de la doctrina. Luis Aguiar de Luque la define como "una institución de carácter excepcional, contornos ambiguos y sobre la que se proyecta una sombra de desconfianza que la convierten en una figura escasamente operativa para fungir como verdadero instrumento de participación directa de los ciudadanos en los asuntos públicos y operar como cauce de modulación de los excesos del régimen parlamentario"38.

El debate se centra en dos elementos del Referéndum. Uno el concepto jurídico de "decisiones políticas de especial trascendencia", que ha recibido numerosas críticas por su imprecisión jurídica. Por ejemplo, ¿se podría utilizar el Referéndum del artículo 92 para someter a consulta popular la ratificación, o derogación, de

37. López González, José Luis: "El referéndum nacional consultivo sobre decisiones políticas de especial trascendencia". Cuadernos Constitucionales de la Cátedra Fadrique Furió Ceriol, n³8/39, Valencia, 2002, pp. 210-211.

38. Aguiar de Luque, Luis (colaborador): "Democracia directa e instituciones de democracia directa en el ordenamiento constitucional español". Op. cit., p. 79. una Ley de las Cortes? Buena parte de la doctrina argumenta que no se puede entender que las disposiciones legislativas tengan cabida en esa definición de "decisiones políticas de especial trascendencia": principalmente porque, en una Constitución de corte parlamentarista, tal disposición hubiera requerido un desarrollo específico como Referéndum legislativo, por su especial entidad ${ }^{39}$. Así, las decisiones que se sometieran a consulta han de ser de carácter exclusivamente político, sin prejuicio de que los resultados de la consulta pudieran tener como consecuencia necesaria el inicio de un proceso legislativo en las Cortes.

¿Cuál es entonces, en definitiva, el objeto del Referéndum del artículo 92? Según la definición del profesor Aguiar de Luque ha de ser una "decisión gubernamental (toda vez que la iniciativa de la convocatoria corresponde al Gobierno de especial trascendencia y carácter básico (esto es, cuya puesta en práctica puede implicar tanto una política legislativa de desarrollo, como unas medidas concretas del gobierno) para que el órgano gubernamental, atendiendo y ponderando los resultados de la consulta popular (formalmente consultivos pero políticamente de mucho mayor significado) impulse y adopte las medidas procedentes para la formalización del veredicto popular" ${ }^{40}$.

Conectando con esta definición, otro elemento muy discutido es el supuesto carácter consultivo de este Referéndum.

39. López González, José Luis: "El referéndum nacional consultivo sobre decisiones políticas de especial trascendencia”. Op. cit., pp. 214-215.

$40 \quad$ Aguiar de Luque, Luis (colaborador): "Democracia directa e instituciones de democracia directa en el ordenamiento constitucional español”. Op. cit., p. 80. 
Es facultativo, sí, en cuanto que el Presidente del Gobierno tiene la potestad, pero no la obligación de convocarlo, lo que implica que ya existe una decisión o, al menos, una intención provisional de decisión por parte de los órganos del Estado, y que simplemente se está consultando al pueblo su parecer. El problema es que resulta difícil concebir que en un Estado democrático las instituciones puedan desoír abiertamente la voluntad del pueblo expresada con todas las garantías de un proceso electoral. Se defiende así, por un sector de la doctrina que el Referéndum, del artículo 92 sería vinculante en la medida en que un Gobierno democrático, basado además en el principio de soberanía popular, no podría adoptar una decisión que contradice claramente la expresión de la voluntad de los electores ${ }^{41}$.

Para Aguiar de Luque, "el veredicto popular en una consulta referendaria tiene materialmente una fuerza vinculante"; aunque reconoce a su vez que dicha fuerza puede aceptarse como matizada en razón del objeto de la consulta o de la intensidad con la que se haya manifestado la voluntad popular (evaluando, por ejemplo, el nivel de participación). Pero esto conlleva que "lo que gana en flexibilidad la institución del referéndum [...] lo pierde en calidad y transparencia. [...] una falta de certeza que, además impropia en un Estado de Derecho, solo puede ser fuente de conflictos y tensiones". Además, como la convocatoria del Referéndum no se asocia a ningún acto formal, se deja a los órganos del Gobierno la facultad de acudir a esta institución con total discrecionalidad, lo que lo convierte, más que en una herramienta jurídica para combatir los ex-

41. López González, José Luis: "El referéndum nacional consultivo sobre decisiones políticas de especial trascendencia”. Op. cit., pp. 216-217. cesos parlamentarios y complementar el sistema representativo, en un instrumento político para dejar en manos del pueblo las decisiones más engorrosas ${ }^{42}$; aunque no debemos olvidar que son los partidos políticos los que organizan las campañas informativas a favor de una u otra opción. En cualquier caso, no se puede negar que un desafío tan flagrante contra la voluntad popular tendría consecuencias políticas severas y nefastas, incluso para un partido que gobierne en mayoría.

\subsection{El Referéndum en la reforma de la Constitución}

El Referéndum de reforma constitucional hace acto de presencia en los artículos 167 y 168 de la Constitución, que cierran el articulado del texto. Esta consulta puede darse en dos modalidades. Si la reforma planteada exige una revisión total del texto, o si afecta, aunque sea parcialmente, a las disposiciones contenidas en el Título preliminar, el Capítulo segundo, Sección primera del Título I, o el Título II (es decir, principalmente los preceptos que afectan a los Derechos Fundamentales o a la configuración de España como una monarquía parlamentaria) será obligatorio pasar por un complejo proceso que requiere la aprobación del texto por dos tercios de las Cámaras, la disolución de las mismas y la convocatoria de nuevas elecciones para a continuación repetir nuevamente el debate y la aprobación del texto por la misma mayoría cualificada de dos tercios de ambas Cámaras. Finalmente, el proceso concluiría con la convocato-

42. Aguiar de Luque, Luis (colaborador): "Democracia directa e instituciones de democracia directa en el ordenamiento constitucional español”. Op. cit., p. 81-82. 
ria de un Referéndum constitucional para la ratificación del proyecto. En cualquier otro caso, se entiende que se remite el proyecto a las disposiciones de reforma parcial del artículo 167, las Cámaras tendrán la opción de convocar Referéndum a iniciativa de, al menos, una décima parte de sus miembros.

La potestad facultativa del artículo 167 no ha sido empleada en ningún momento durante las dos únicas reformas que ha visto nuestra Constitución, en 1992 y 2011; principalmente, porque ambas revisiones del texto constitucional vinieron exigidas por compromisos contraídos por el Estado español para con la Unión Europea, por lo que contaron con el apoyo de los grandes partidos mayoritarios. Se han hecho varios comentarios por parte de la doctrina al Referéndum facultativo previsto en este artículo, existiendo autores que consideran que el quórum del 10 por ciento de las Cámaras resulta excesivamente bajo y puede ocasionar situaciones de bloqueo constitucional43.

Pero las críticas más feroces las ha recibido el procedimiento agravado de reforma del artículo 168. Es perfectamente admisible que el Referéndum forme parte de los procesos de revisión constitucional, en tanto que obliga a que el proyecto de reforma se someta a juicio del pueblo, soberano y originario del poder constituyente; este requisito cobra especial sentido cuando se tiene en cuenta que el artículo 168 exige el procedimiento agravado para la reforma de los preceptos constitucionales donde se contienen los Derechos Fundamentales de más alto grado. Pero también es cierto, y así lo ha señalado numerosas veces la doctrina, que este proceso agravado resulta innecesariamente complicado, redundante y muestra una clara intención por parte del constituyente de 1978 por entorpecer en todo cuanto pudiera la reforma de la Constitución. Ya es harto difícil alcanzar los consensos requeridos para reunir las elevadas mayorías exigidas de dos tercios en cada Cámara, y parece innecesario repetir el debate una segunda vez después de haber disuelto las Cortes, acudido a elecciones y formado un nuevo legislativo. Además, someter el proyecto de reforma a Referéndum parece no aportar nada al procedimiento si el pueblo ya ha tenido ocasión de pronunciarse durante el proceso electoral previo, durante el cual, sin duda alguna, la ratificación de la reforma habrá sido el elemento central de las campañas electorales de todos los partidos ${ }^{44}$.

Además, la selección de disposiciones a las que se les otorga la especial protección del artículo 168 plantea una serie de incoherencias. Dicha enumeración se hace de forma genérica y expansiva, por Secciones, Capítulos o Títulos, por lo que, a menudo, quedan incluidos en la selección artículos para los que difícilmente se puede justificar la exigencia de un procedimiento tan estricto de reforma. Por ejemplo, habría que acudir al 168 si quisiéramos cambiar los colores de la bandera o trasladar la capital de la nación a otra ciudad distinta de Madrid, o para anular la polémica disposición sexista que prima a los varones sobre las mujeres en la sucesión a la Corona.
43. Cascajo Castro, José Luis, García, Eloy, Oliver Araujo, Joan, \& Torres Muro, Ignacio: "Encuesta sobre el referéndum". UNED, Teoría y Realidad Constitucional, $n^{\circ} 30,2012$, pp. 38-39.
44. Oliver Araujo, Joan: "El referéndum en el sistema constitucional español”. Op. cit., p 150151. 


\subsection{El Referéndum de ámbito autonómico}

La modalidad autonómica del Referéndum cobra también una gran relevancia, viniendo prevista en dos procedimientos distintos: el procedimiento especial de autonomía del apartado 1 del artículo 151, y la elaboración y reforma de los Estatutos de Autonomía.

En cuanto al primer supuesto, empezaremos por recordar que, en la Constitución Española, existen dos procedimientos por los cuales un territorio puede acceder al autogobierno y configurarse como Comunidad Autónoma: el procedimiento ordinario del artículo 143 y el especial del artículo 151. El artículo 151 nos resulta de especial interés porque exige que la iniciativa autonómica, para prosperar, debe ser ratificado por el voto afirmativo de la mayoría absoluta de los electores de cada provincia de la región que pretenda acceder a la autonomía. Solo Andalucía optó por invocar las disposiciones del artículo 151, lo que dio inicio a un complejo proceso de autonomía que suscitó una gran controversia, obligando incluso a reformar, con efectos retroactivos, la Ley Orgánica de Modalidades de Referéndum. Por lo demás, ninguna otra Comunidad Autónoma hizo uso del artículo 151, por lo que estos preceptos han quedado obsoletos a día de hoy ${ }^{45}$.

Las regiones que accedan a la autonomía según el proceso establecido en el artículo 151 tendrán que elaborar y aprobar sus Estatutos de Autonomía según los pasos previstos en el apartado 2 de dicho artícu-

45. Aguiar de Luque, Luis (colaborador): "Democracia directa e instituciones de democracia directa en el ordenamiento constitucional español". Op. cit., p. 84. lo. En dicho caso, para que un proyecto de Estatuto pueda ser aprobado, requiere de haber sido ratificado en Referéndum por la mayoría de los votos válidamente emitidos en cada provincia de la Comunidad Autónoma en cuestión; solo entonces podrá el proyecto de Estatuto ser elevado para su debate en las Cortes. Además, el artículo 152 prevé que la modificación de un Estatuto Autonómico ratificado por este método solo podrá llevarse a cabo mediante la convocatoria de un nuevo Referéndum. Además de Andalucía, las Comunidades Autónomas de Cataluña, País Vasco y Galicia ratificaron sus respectivos Estatutos de Autonomía según el procedimiento referendario del artículo $151^{46}$.

46. Cuesta López, Víctor Manuel: "Participación directa e iniciativa legislativa del ciudadano en democracia constitucional". Op. cit., p. 91. El profesor Cuesta López también nos muestra las cifras de participación en estos refrendos. Además de Andalucía, Cataluña, País Vasco y Galicia convocaron sendos Referéndums de aprobación para sus respectivos Estatutos de Autonomía. En el caso concreto de País Vasco y Cataluña, dado que aún no había sido adoptada la Ley Orgánica de desarrollo de los preceptos constitucionales en cuanto a los procesos referendarios, el procedimiento se llevó a cabo siguiendo las disposiciones del Real Decreto 2120/1978, el mismo que había servido para regular el proceso constituyente de 1978. Aunque las cuatro Comunidades lograron ratificar sus Estatutos con un elevadísimo grado de aprobación popular (más del $90 \%$ de votos afirmativos en los casos andaluz, catalán y vasco, y más del 70\% en la consulta gallega), sí es cierto que los niveles de participación fueron sorprendentemente bajos, sin alcanzar el $60 \%$ en ninguna de las cuatro consultas; de hecho, en Galicia ni siquiera se llegó al 30\%. Sea como fuere, dado que la Constitución no hace referencia a ningún quorum determinado para la validez de dichos Referéndums, estas cifras bastaron para sacar adelante los Estatutos. En el caso particular de la Comunidad Valenciana, desde la reforma de su Estatuto en 2006, también se exige que la 
Uno de los problemas que, a juicio de la doctrina, causa esta desigual regulación constitucional es la disparidad entre la rigidez de los distintos Estatutos de Autonomía. Cierto es que, a nivel estrictamente formal, los Estatutos se aprueban en las Cortes como Leyes Orgánicas (artículo 81.1 de la Constitución) y, según la doctrina reciente del Tribunal Constitucional, "su posición en el sistema de fuentes es, por tanto, la característica de las leyes orgánicas" ${ }^{47}$. Pero la doctrina también afirma que la posición de una norma en el ordenamiento no se determina solamente por su procedimiento de elaboración o de reforma ${ }^{48}$. Los Estatutos de Autonomía son la norma institucional básica de las Comunidades Autónomas en tanto que suponen el acceso de estas regiones a su autogobierno; algunos autores denominan a este tipo de normas como "materialmente constitucionales" o "bloque de constitucionalidad" ${ }^{49}$. Por lo tanto, parce

Generalitat convoque un Referéndum para poder reformar dicho Estatuto.

47. STC 31/2010, FJ $3^{\circ}$.

48. Aguiar de Luque, Luis (colaborador): "Democracia directa e instituciones de democracia directa en el ordenamiento constitucional español”. Op. cit., p. 85.

49. Rubio Llorente, Francisco: "El bloque de constitucionalidad". Revista Española de Derecho Constitucional, $\mathrm{n}^{\circ} 27,1989$, p. 25. Nos remitimos, en particular, a este ilustrativo fragmento sobre el concepto de bloque de constitucionalidad: La heterogeneidad de las normas que lo integran impide incluirlas en el concepto de Constitución, que, como concepto jurídico formal, sólo en parte las engloba, pero su común naturaleza materialmente constitucional hace imposible regatearles, al menos, el adjetivo [...]. En su parte más importante, el bloque de la constitucionalidad está formado por normas también formalmente constitucionales. Unas, recogidas en el Título VIII de la Constitución, son normas primarias; otras, las que forman el cuerpo central del bloque, esto es, las normas una contradicción que solamente algunos de estos Estatutos requieran un pronunciamiento directo por parte de la población para su reforma.

Esto nos lleva a otro conflicto: ¿tienen las Comunidades Autónomas la potestad para convocar un Referéndum? Cuando la Constitución realiza el reparto de competencias recoge expresamente, en su artículo 149.1.32a que el Estado tiene competencia exclusiva sobre la autorización para la convocatoria de consultas populares por vía de referéndum. Y parte de la doctrina afirma que, de hecho, las únicas modalidades de consulta popular que pudieran llevarse a cabo en un territorio autonómico serían aquellas previstas para la reforma estatutaria según el artículo 152, y el Referéndum consultivo del artículo 92, contando con la autorización estatal. Esta es una posición discutida: Aguiar de Luque la considera "una innecesaria reducción de las facultades autonómicas de organizar sus propias instituciones de autogobierno" 50 .

La jurisprudencia del Tribunal Constitucional se ha mostrado siempre restrictiva con la posibilidad de convocar consultas populares de carácter referendario por parte de las Comunidades Autónomas. Esta jurisprudencia se define mayormente a partir de la Sentencia 103/2008,

de delimitación competencial contenidas en los Estatutos de Autonomía, son normas constitucionales secundarias. La afirmación no escandalizará, espero, a nadie, pues muchas veces se ha dicho ya que los Estatutos tienen un rango superior al resto de las leyes, orgánicas u ordinarias, y esta superioridad de rango es la que califica normalmente a las normas constitucionales secundarias o leyes constitucionales".

50. Aguiar de Luque, Luis (colaborador): "Democracia directa e instituciones de democracia directa en el ordenamiento constitucional español". Op. cit., pp. 86-87. 
referente a la Ley del Parlamento Vasco 9/2008, "de convocatoria y regulación de una consulta popular al objeto de recabar la opinión ciudadana en la Comunidad Autónoma del País Vasco sobre la apertura de un proceso de negociación para alcanzar la paz y la normalización política"51. Esta norma venía a autorizar al Lehendakari para convocar una consulta en la cual se preguntaba a los ciudadanos vascos respecto de un hipotético "proceso de final dialogado de la violencia" entre las autoridades vascas y el grupo terrorista ETA; y también se sometía a juicio ciudadano si los partidos vascos debieran "alcanzar un Acuerdo Democrático sobre el ejercicio del derecho a decidir del Pueblo Vasco, y que dicho Acuerdo sea sometido a referéndum", lo que generaría aún más controversias. El Tribunal Constitucional terminaría, como era previsible, declarando la inconstitucionalidad de esta Ley, pues, según sus propias palabras: "no cabe en nuestro ordenamiento constitucional, en materia de referéndum, ninguna competencia implícita, puesto que en un sistema, como el español, cuya regla general es la democracia representativa, sólo pueden convocarse y celebrarse los referendos que expresamente estén previstos en las normas del Estado, incluidos los Estatutos de Autonomía, de conformidad con la Constitución"52.

Si la STC 103/2008 vendría a pronunciarse en el contexto del movimiento nacionalista vasco, sus líneas jurisprudenciales se verían desarrolladas posteriormente en la también controvertida STC 31/2010, sobre la reforma del año 2006 del Esta-

51. Martín Núñez, Esther: "El referéndum y las consultas populares en las Comunidades Autónomas y municipios". Revista Vasca de administración pública, nº4, 2012, pp. 109-110.

52. STC 103/2008, FJ $3^{\circ}$. tuto de Autonomía de Cataluña. La doctrina de la Sentencia de 2010 es aún más restrictiva que la de 2008: si bien reconoce que no es inconstitucional atribuir a las autonomías la competencia convocar consultas populares de carácter no referendario, toda aquella consulta que se ajuste al concepto de Referéndum propuesto en la STC 103/2008 (que ya explicábamos al principio de este apartado) requeriría de autorización estatal. Pero, para el Tribunal, la reserva impuesta por el artículo 149.1.32 ${ }^{\mathrm{a}}$ no se entiende solo con respecto de la autorización para la convocatoria del Referéndum, sino que "ha de extenderse a la entera disciplina de esa institución, esto es, a su establecimiento y regulación" ${ }^{53}$. En pocas palabras, el Referéndum se define como una competencia exclusiva del Estado, en todos sus aspectos Como ya diría en 2008 , "la Ley Orgánica 2/1980, de 18 de enero, sobre regulación de las distintas modalidades de referéndum, es la llamada por el art. 92.3 CE para regular las condiciones y el procedimiento de las distintas modalidades de referéndum previstas en la Constitución, siendo además la única Ley constitucionalmente adecuada para el cumplimiento de otra reserva, añadida a la competencial del art. 149.1.32 CE: la genérica del art. $81 \mathrm{CE}$ para el desarrollo de los derechos fundamentales, en este caso el derecho de participación política reconocido en el art. 23 CE"54.

\subsection{El desarrollo legislativo de la institución referendaria}

Concluimos este apartado haciendo referencia a la Ley Orgánica 2/1980, de 18

53. STC 31/2010, FJ $69^{\circ}$.

54. STC $103 / 2008, \mathrm{FJ}^{\circ}$. 
de enero, sobre regulación de las distintas Modalidades de Referéndum (en adelante, LOMR), como la norma de desarrollo que contiene las disposiciones más específicas de esta figura. Esta Ley se dicta en obediencia al mandato previsto en el último apartado del artículo 92 de la Constitución, que establece: "una ley orgánica regulará las condiciones y el procedimiento de las distintas modalidades de referéndum previstas en esta Constitución". Así pues, las disposiciones de la Ley Orgánica son aplicables a las tres modalidades de Referéndum: consultivo, autonómico y constitucional. Lo único que quedaría fuera de su regulación, y así lo señala en su Disposición Adicional, serían las consultas populares municipales que ya vimos reguladas en la LRBL.

La doctrina ha sido muy crítica a la hora de evaluar la LOMR, crítica que podemos resumir en tres puntos: primero, el contenido desproporcionado de la norma, que regula de forma exhaustiva la modalidad autonómica de Referéndum, mientras que deja a las modalidades constitucional y consultiva con una regulación escasa e insuficiente; segundo, las características restrictivas de la Ley, que se limita a un desarrollo estricto y simplista de los preceptos constitucionales, sin explorar las posibilidades y virtudes democratizadoras del Referéndum; y tercero, sus marcadas deficiencias técnicas, que han sido objeto de duros comentarios por la doctrina por sus numerosísimos errores y defectos técnicos que, para muchos, son más comunes que sus aciertos ${ }^{55}$.

Nos encontramos ante una Ley corta, compuesta por menos de 20 artículos y

55. Oliver Araujo, Joan: "El referéndum en el sistema constitucional español”. Op. cit., pp. 144146. algunas disposiciones transitorias y finales. No ofrece más desarrollo que detalles formales y de procedimiento, que no añaden demasiado al contenido material de la institución. Mayormente, podemos destacar que, en su artículo 2, se concede al Estado, en exclusiva, la potestad para convocar una consulta popular de cualquier modalidad, tal y como viene previsto en la atribución de competencias estatales del artículo 149 de la Constitución; y esto incluye, por supuesto, el Referéndum autonómico, como así lo enfatizaba el Tribunal Constitucional. Se prohíbe en todo caso que se celebre un Referéndum durante los estados de excepción y sitio, o durante los noventa días anteriores y posteriores a la celebración de elecciones, ya sean generales o regionales en el territorio de la consulta. También resulta interesante resaltar que únicamente los grupos políticos con representación en las Cortes (esto es, los partidos que hayan logrado acceder a las Cámaras durante las últimas elecciones) podrán hacer uso de los espacios gratuitos que concedan los medios de comunicación públicos durante la campaña.

Precisamente por lo breve de su redacción suele criticarse que la LOMR deja muchas cuestiones sin aclarar. Por ejemplo, respecto de la participación ciudadana, no se menciona ningún requisito de quórums participativos para considerar válida la consulta, salvo en el artículo 8, que desarrolla, como ya sabemos, el proceso especial para acceder a la autonomía previsto en el artículo 151 del texto constitucional. Tampoco se especifica cuáles son las condiciones que se exigen para que una persona pueda participar en los distintos Referéndums (por ejemplo, si son solamente de ámbito territorial), o si debieran exigirse unas mayorías cualifica- 
das en relación con el especial objeto de determinadas consultas. Pero la carencia más preocupante para buena parte de la doctrina es la ausencia de previsiones en caso de que la consulta obtenga una respuesta negativa por parte de los votantes. ¿Podría repetirse la consulta? Parecería incoherente para con el sentido del Referéndum si el Estado pudiera simplemente repetir el proceso una y otra vez hasta obtener los resultados que desee. De nuevo, solo respecto del procedimiento especial de acceso a la autonomía se prevé una consecuencia para un hipotético resultado negativo, y es que la iniciativa autonómica no podría volver a plantearse hasta pasados cinco años. En cuanto a los temas procedimentales, la LOMR contiene una previsión de remisión a lo previsto en los procesos electorales, que actualmente vienen regulados por la Ley Orgánica 5/1985, del Régimen Electoral General56.

\section{Referéndum: las posiciones de la doctrina}

\subsection{Sintetizando la doctrina}

Hagamos referencia a algunos puntos de vista que la doctrina española tiene que aportar con respecto a la situación en la que se encuentra la institución del Referéndum en el orden constitucional vigente en España ${ }^{57}$.

56. Linde Paniagua, Enrique, y Herrero Lera, Miguel: "Comentario a la Ley Orgánica de Modalidades de Referéndum". Revista de Derecho Politico, nº, UNED, pp. 101-105.

57. Cascajo Castro, José Luis, García, Eloy, Oliver Araujo, Joan, \& Torres Muro, Ignacio: "Encuesta sobre el referéndum”. Op. cit., pp. 11-56. Aunque dicha encuesta se hizo en torno a una serie de preguntas específicas, para su mejor expo-
El profesor José Luis Carrasco Castro opina que el temor que se manifestó hacia la democracia directa durante la transición fue exagerado e injustificado, y solo sirvió para poner demasiado énfasis en un sistema de partidos que ha terminado por sobreexpandirse y colonizar todos los aspectos de la vida pública. Para él, la cuestión no pasaría tanto por ampliar los supuestos constitucionales del Referéndum, sino de profundizar en su regulación para convertirlo en un proceso más eficiente de toma de decisiones colectivas, reformando la Ley Orgánica (para, por ejemplo, estudiar si las Comunidades Autónomas podrían convocar un Referéndum consultivo en el ámbito de sus competencias). Particularmente critica la indeterminación y la ambigüedad de su actual regulación, así como las omisiones que presenta la Ley Orgánica, que no es capaz de establecer un régimen jurídico general claro ni dar respuesta a cuestiones de tan vital importancia como los quórums de participación necesarios para considerar válida la consulta. También nos recuerda el importante papel que debe jugar el Referéndum en la reforma constitucional, como medio de conexión entre las instituciones políticas y la voluntad soberana del pueblo, de la que todo texto constitucional debe aspirar a ser máxima expresión.

También citaremos al profesor Eloy García, el cual hace un particular énfasis en entender la democracia directa en general, y el Referéndum en particular, como un poder legal cuya función está integrada en un sistema de contrapesos: lo que los estadounidenses vienen denominando el sistema de checks and balances de los órganos del poder. El Referéndum sería,

sición hemos decidido sintetizarlas en sus puntos principales y recalcando aquellos detalles que, creemos, serán de mayor interés para los lectores. 
desde esta concepción, una herramienta de control de los poderes públicos en los cuales debe verse materializada la voluntad popular soberana, particularmente cuando estos órganos se vean bloqueados por conflictos de intereses. El Referéndum sería pues una forma de solucionar estos conflictos que impiden el funcionamiento ordinario de las instituciones representativas y permitir que el sistema vuelva a su cauce. Señala el profesor García que esta visión del Referéndum puede verse claramente plasmada en el constitucionalismo Suizo posterior a 1848, así como en el texto de la Constitución de Weimar. Sin embargo, también debemos señalar que, desde su punto de vista, son los partidos los que deben formar, en todo momento, el corazón latente del sistema: y que, en un contexto donde dichos partidos han entrado en crisis y la población ha dado la espalda a la política, la democracia directa podría pasar a convertirse en una peligrosa arma demagógica de caer en las manos menos adecuadas.

Una perspectiva interesante nos la ofrece también el profesor Joan Oliver Araujo, el cual vuelve a recordarnos que las propuestas iniciales de regulación del Referéndum durante el proceso constituyente del 78 fueron mucho más ambiciosas que lo que finalmente se recogió en el texto constitucional. Señala que las coyunturas de la transición, si bien comprensibles, no bastan para justificar que siga existiendo los mismos recelos hacia la democracia participativa cuarenta años después. Si bien es cierto que el Referéndum ha sido utilizado por regímenes autoritarios con el mero fin de justificar su poder dictatorial, esto no significa que se pueda calificar la institución en sí misma como antidemocrática. En efecto, un Referéndum que se lleve a cabo en un Estado de Derecho, donde exista un pluralismo político y unos Derechos Fundamentales garantizados, sobre una materia adecuada y con una pregunta correctamente formulada (que no sea excesivamente técnica), y un adecuado control de los medios de comunicación de masas de titularidad pública, no presenta en principio ningún problema con respecto a su validez democrática.

El último al que haremos referencia será el profesor Ignacio Torres Muro, para aportar una perspectiva más crítica para con la institución. Reconoce que el Referéndum puede tener un uso excepcional, pero desconfía de las consultas populares en cuanto que obligan a reducir las cuestiones políticas a una pregunta de respuesta sencilla, entre el "sí" y el "no", lo que puede llevar a simplificar en exceso materias cuya complejidad exige un debate más profundo y exhaustivo. Recela también de un electorado al que califica como "irresponsable", y pone en duda su capacidad para tomar estas decisiones. Más aún, no solo considera innecesario ampliar la regulación que actualmente tiene la institución referendaria, sino que incluso plantea si los supuestos que sí han sido regulados en nuestro ordenamiento tienen razón de ser. Muy dura es su crítica al Referéndum consultivo, al que considera casi una farsa, que ha servido de poco más que un teatro para que algunos Gobiernos puedan justificar sus decisiones en base a los resultados de unas consultas en cuyas campañas apenas ha existido debate, ni se han realizado propuestas alternativas reales a las planteadas por el poder vigente. Dice Torres Muro que el "fantasma" plebiscitario todavía pende sobre estas consultas. Concluye sus reflexiones recordando que para hablar de un Referéndum "limpio" ambas opciones deben haberse podido 
defender en el debate político en igualdad de oportunidades, en lugar de que, como venimos observando recientemente, se imponga claramente la campaña a favor de aquellas opciones que más favorezcan al poder establecido, pues entonces el Referéndum como medida de contrapeso político perdería todo su sentido. Particularmente resalta la necesidad de una normativa que impida el monopolio mediático de las redes y medios de comunicación por parte de los gobernantes, pues solo se podrá hablar de verdadero Referéndum cuando exista igualdad desde la campaña. También hace referencia a la exigencia de un quórum determinado para garantizar la validez de la consulta, y considera razonable que se exija, al menos, la participación de la mitad del cuerpo electoral; y, en todo caso, un quórum reforzado para aquellas consultas cuyo objeto revista de una especial relevancia política y social.

\subsection{El debate referendario: ¿un complemento a la representación?}

La institución del Referéndum ha recibido, a grandes rasgos, tres importantes críticas $^{58}$. Para empezar, el Referéndum responde a una lógica distinta que la democracia representativa clásica: mientras que el sistema representativo implica la sustitución del pueblo por unos grupos de representantes que actúan en su nombre, las instituciones participativas responden más a las concepciones rousseaunianas del ideal democrático y el autogobierno. Aquí es donde tienen su origen aquellas

58. Oliver Araujo, Joan: "El referéndum en el sistema constitucional español”. Op. cit., pp. 130133. líneas de pensamiento que afirman la incompatibilidad de ambos modelos democráticos, en la medida en que responden a concepciones radicalmente distintas de cómo debe funcionar el Estado democrático.

Otro de los principales argumentos son los precedentes plebiscitarios ${ }^{59}$ del Referéndum, esto es, aquellas situaciones en las que un Gobierno cuyo poder ha sido conquistado mediante medios no democráticos convoca una consulta popular con la intención de justificar y legitimar dicha autoridad; particularmente, en aquellos Estados autoritarios, como puede ser la Francia napoleónica, la Alemania de Adolf Hitler o la España franquista, donde las consultas se llevaron a cabo sin las menores garantías de libertad o pluralismo que garantizaran la legitimidad democrática de la votación. Hemos hecho menciones a varias de estas situaciones a lo largo del texto: el plebiscito ha sido, en efecto, una de las herramientas predilectas por las dictaduras para justificar su autoridad y mantener el statu quo. Ello se debe a que resulta sencillo para estos Gobiernos dictatoriales manipular el procedimiento y los resultados de la consulta, bien sea mediante el fraude, la coerción de la libertad de expresión o el uso directo y claro de la violencia.

Por último, desde un punto de vista más pragmático, algunos autores consideran que el Referéndum ha perdido su razón de ser en los Estados democráticos mo-

59. Entiéndase que no pretendemos emplear el término "plebiscitario" con connotaciones peyorativas. Nos expresamos desde una perspectiva estrictamente histórica del constitucionalismo, sin prejuicio de que, en un contexto moderno y abierto, esta palabra pueda limpiarse de sus viejas connotaciones negativas y adquirir una significación completamente renovada. 
dernos. Esto se debe a que el sistema de partidos ya incorpora una comunicación directa entre las instituciones y el electorado en la forma de sus campañas y consultas electorales: cualquier tema que sea de gran relevancia para la sociedad y la política del momento ocupará un lugar central a lo largo de todo el proceso electoral y en los discursos de los candidatos. Esto implica que los partidos tendrán que ofrecer soluciones a esas cuestiones clave que despiertan el interés de la ciudadanía, y los votantes, al acudir a las urnas, podrán decantarse por aquella fuerza política cuyas propuestas le resulten más satisfactorias. A tal juicio las campañas electorales resultan ya suficientes para que los partidos recaben información, ya sea mediante consultas, encuestas o cualquier otro método, sobre las preferencias del ciudadano y puedan traducir dichas opiniones en un curso de acción política determinada; por tanto, el Referéndum como tal no tendría nada que aportar al proceso político.

Nosotros preferimos, en nuestra discrecionalidad, posicionarnos junto con aquellos sectores de la doctrina que defienden la validez del Referéndum como una institución que aún tiene una razón de ser en los modernos Estados democráticos. Como dice Jorge de Esteban, no se trata de defender una supuesta "santificación democrática" de la institución ${ }^{60}$, ni pretender que participación ciudadana es la panacea que solucionará todos los problemas de la democracia. Mas sí se puede argumentar que Referéndum podría ser una herramienta productiva para el Estado democrático, en la medida en la que refuerza la conexión entre los ciudadanos y las instituciones políticas.

60. De Esteban, Jorge (coautor): "El régimen constitucional español, volumen 1", Labor Universitaria, Barcelona, 1980, p. 92.
La democracia participativa, a día de hoy, ya no busca plantear un modelo alternativo que sustituya al representativo, sino integrarse precisamente en este sistema de designación de representantes y servir como un corrector de los excesos del régimen parlamentario, para reducir el monopolio que la clase política profesionalizada ostenta sobre el proceso de toma de decisiones. Como dice el profesor Aguiar de Luque, el recelo con el que se le trata en el constitucionalismo español "tampoco parece coherente con el principio general consagrado en el artículo 9.2 CE con la configuración que el artículo 23 CE realiza de la participación directa, la desnaturalización del referéndum como materialización del principio democráticoparticipativo que el régimen jurídico de esta figura ha comportado"61.

Coincidimos, en parte, con la línea de pensamiento que desarrollaba el profesor Eloy García en el punto anterior: el sistema de partidos políticos conforma el núcleo de la democracia moderna. Es lo que el Miguel Ángel Presno Linera denomina "la primacía de partidos en las instituciones públicas", es decir, cómo los partidos modernos se definen por "los patrones institucionales en los que se muevan, su capacidad de maniobra y su influencia real en los procesos de toma de decisiones"62. Los partidos políticos están asentados por completo en las instituciones, hasta

61. Aguiar de Luque, Luis (colaborador): "Democracia directa e instituciones de democracia directa en el ordenamiento constitucional español”. Op. cit., pp. 69 y 83.

62. Presno Linera, Miguel Ángel (coordinador): "Partidos políticos y movimientos ciudadanos en la sociedad del riesgo y la desconfianza". Fundamentos: Cuadernos monográficos de teoría del estado, derecho público e historia constitucional, no8, 2014, p. 222-223. 
tal punto que las propias estructuras internas de poder del partido están profundamente relacionadas con las posiciones y cargos institucionales que ocupan los miembros del mismo. En un sistema parlamentario como es el español, esto viene a implicar que los partidos están presentes en cada momento del proceso legislativo, y controlan la totalidad del mismo. Eso quiere decir que una crisis del sistema de partidos implica también una crisis de todo el entramado institucional, y del conjunto del Estado democrático. Como es evidente, la tan mentada regeneración de los partidos tendrá que pasar, necesariamente, por una extensa actividad legislativa dirigida expresamente a reparar las grietas del sistema: regulando el sistema de financiación de los partidos para reducir su dependencia para con las grandes fuerzas del mercado; exigiendo un mayor grado de democracia en el gobierno interno de los partidos y la designación de sus líderes; persiguiendo con mayor dureza la corrupción y el fraude a Hacienda; entre otras diversas.

Con toda seguridad, si aumentamos las modalidades y posibilidades de democracia directa en nuestro ordenamiento jurídico, los partidos políticos también se convertirán en los protagonistas de estos procesos. Así ocurre en Suiza, donde, según la profesora Eva Sáenz Royo, la institución del Referéndum, lejos de debilitar a los partidos, los ha convertido en estructuras más fuertes y profesionalizadas ${ }^{63}$. Los partidos políticos actúan como impulsores y ejes del procedimiento participativo, recurriendo ellos mismos con mucha frecuencia a los instrumentos participativos.

63. Sáenz Royo, Eva: "La regulación y la práctica del referéndum en Suiza: un análisis desde las críticas a la institución del referéndum." $O p$. cit., p. 84-85.
Y es precisamente por todo lo que acabamos de exponer que nos posicionamos contra las críticas tradicionales al Referéndum como instrumento participativo. Si entendemos que los partidos políticos son indispensables para el buen funcionamiento del modelo representativo en un Estado constitucional, y que, por ello, toda crisis institucional viene derivada de una crisis del sistema de partidos, la crítica a la democracia directa pierde su sentido. Es una sencilla cuestión de lógica: en la medida en que la participación directa es una mera adición al modelo representativo, que solo puede aspirar a mejorarlo, nunca a sustituirlo, tampoco se puede culpar a las instituciones participativas de la crisis del modelo. Cuando el sistema es esencialmente representativo, las crisis son, precisamente, crisis de representación.

En cuanto a los precedentes plebiscitarios del Referéndum, es bien cierto que los grandes dictadores de la historia reciente, como Francisco Franco o Adolf Hitler, han utilizado el plebiscito como herramienta para justificar su poder: Franco convocaría la consulta de 1947 para convertir en vitalicio el cargo de Jefe de Estado, del mismo modo que haría Hitler con el Referéndum plebiscitario de 1934 para concentrar los poderes del ejecutivo en la persona del Führer; pero estos hombres, y las fuerzas que los apoyaban, ya habían accedido a las instituciones cuando celebraron estas consultas. Ya sea mediante un golpe de Estado de carácter militar, o por la victoria electoral de un partido populista y de ultraderecha, una vez que se les abre a estos regímenes las puertas de los poderes públicos, la democracia está herida de muerte. Un régimen autoritario y antidemocrático puede manipular una consulta popular para legitimar su gobierno, sí; pero con la misma facilidad podría 
organizar un proceso electoral y garantizar su victoria mediante métodos intimidatorios y fraudulentos.

Respondiendo también a los autores que afirman la irrelevancia del Referéndum en los Estados contemporáneos que se organizan según un sistema de partidos, pues estos partidos ya hacen referencia a las principales cuestiones y controversias sociopolíticas que preocupan a la población en el momento de la campaña electoral; y los votantes tienen la posibilidad de decantarse por una propuesta u otra votando al partido en cuyo discurso se sientan mejor representados. Dicho en plata, el Referéndum no es necesario porque los debates electorales ya giran en torno a todos los asuntos que interesan a los electores. Pero este argumento no se puede tener por válido sencillamente porque los partidos pueden incumplir sus promesas electorales y de hecho lo hacen muy a menudo. Hemos citado numerosos autores, como Presno Linera o Pérez Luño, que han denunciado esta desconexión entre los partidos y la ciudadanía, y la pérdida de confianza que ello ha originado en el sistema de partidos. En la medida el que el mandato representativo no es de carácter imperativo, no existen consecuencias jurídicas para un partido que no cumple con lo prometido en campaña. Precisamente ahí es donde entra en juego una de las principales facetas de la democracia directa como sistema de control ciudadano postelectoral.

\subsection{La validez democrática del Referéndum}

Jorge de Esteban afirma que se deben exigir tres requisitos para conseguir una "validez realmente democrática" de la institución del Referéndum ${ }^{64}$. El primero sería, como es evidente, que se lleve a cabo en un "contexto democrático": esto es, que exista un pluralismo político y unos derechos fundamentales garantizados. Esto implica, como es evidente, que el Referéndum no puede ser la única vía de participación ciudadana, sino que debe darse en un Estado donde dicha participación sea un derecho reconocido y de ordinario ejercicio: lo que viene a requerir un modelo constitucional con un sistema representativo activo y legítimo, organizado por partidos que sirvan de puente entre los ciudadanos y las instituciones. Estos mismos partidos serán los que organizarán las campañas de información ciudadana y los espacios de debate donde se podrán deliberar sobre las opciones en cuestión, las ventajas y desventajas de cada una, para tratar de convencer al público y recabar el apoyo popular.

Querríamos añadir, a este primer punto, algunas consideraciones sobre la importancia de un Estado de Derecho vigente y constitucionalmente protegido para la validez del Referéndum. En efecto, toda Constitución que aspire a ser la norma fundamental de un Estado en el que rige el principio de legalidad debe imponerse, primero y sobre todo, como un baluarte para la protección de los Derechos Fundamentales de todas las personas. Y, en el contexto del Derecho Internacional, los textos constitucionales contemporáneos vienen reforzados por una serie de instrumentos como pueden ser la Declaración Universal de los Derechos Humanos o la Carta de los Derechos Fundamentales de la Unión Europea, que han de ser recono-

64. De Esteban, Jorge (coautor): "El régimen constitucional español, volumen 1", Labor Universitaria, Barcelona, 1980, p. 92. 
cidos y respetados por las instituciones del Estado. Esto implica que se deben imponer una serie de controles para asegurar que el objeto del Referéndum no supone una violación de los Derechos Fundamentales. En Suiza, con sus largas y prestigiosas tradiciones de democracia directa, el Referéndum ha sido, en contadas pero sonadas ocasiones, un obstáculo al desarrollo de los Derechos Fundamentales: nos referimos a la tardía incorporación del sufragio femenino (la más tardía, de hecho, de los Estados occidentales) y, más recientemente, a la prohibición para la construcción de minaretes en las mezquitas islámicas ${ }^{65}$. Estos problemas vinieron dados, como ya habíamos señalado en el capítulo pertinente, por el carácter conservador de la población helvética que, como no podría ser de otra manera, también se ve claramente manifiesto cuando los ciudadanos suizos acuden a las urnas. Es por ello que nos vemos en la obligación de insistir especialmente en que se deben establecer controles sobre el uso de la institución referendaria para asegurar su respeto a los Derechos Humanos; al fin y al cabo, es precisamente para la solución de esta clase de controversias que los Estados democráticos modernos establecen Tribunales Constitucionales.

La segunda exigencia viene dada en referencia al "planteamiento de la pregunta" que se le hace al pueblo. Como afirma el profesor Jorge de Esteban, una pregunta mal planteada, o excesivamente técnica, crearía confusión respecto del objeto de la consulta o su legitimidad. También entra en juego el grado de educación y cultura del cuerpo electoral: "una pregunta

65. Sáenz Royo, Eva "La regulación y la práctica del referéndum en Suiza: un análisis desde las críticas a la institución del referéndum." $O p$. cit., p. 88. excesivamente compleja, o la existencia de un cuerpo electoral de analfabetos, invalidaría asimismo democráticamente la consulta". También recuerda Jorge de Esteban que no deben perderse de vista los estudios sociológicos sobre las tendencias del cuerpo electoral, y cita autores que afirman que, por lo general, se oscila más hacia el "sí" que hacia el "no".

El último requisito estaría relacionado con la utilización de los medios de comunicación, en la medida en que debe regularse un acceso justo y equitativo a los mismos por parte de todas las fuerzas políticas en defensa de cualquier posicionamiento ante la consulta; al mismo tiempo que se debe controlar la imparcialidad del Gobierno en el uso de estos medios, sin abusar de ellos. En cuanto a este requisito, la hegemonía actual de los medios privados de comunicación frente a los medios públicos, así como la expansión de las nuevas tecnologías y las redes virtuales, pueden llegar a plantear candentes debates, especialmente si entramos a deliberar sobre hasta qué punto es el ciudadano libre en el acceso a la información, y los riesgos de que las propuestas minoritarias queden sepultadas por una sobreexposición al discurso mayoritario impulsado por las élites que controlan los principales canales de difusión. Aunque no sea el momento de entrar en estas cuestiones, queremos que el lector las tenga presentes.

Hemos dado ya nuestra respuesta a la que consideramos la crítica más importante hacia la institución del Referéndum, que es la alusión a sus precedentes plebiscitarios. Por resumir, concluimos que estos riesgos no son suficientes para desacreditar la validez de la institución. Nuestro Tribunal Constitucional, en su ya citada Sentencia 103/2008, distingue el Referéndum de otras modalidades de 
consulta popular en que el primero viene dirigido hacia el cuerpo electoral y, por tanto, debe equipararse en garantías a las mismas que cualquier proceso electoral. En otras palabras: un Estado que no es capaz de asegurar esas garantías, no puede proclamarse democrático. Si se puede manipular fraudulentamente una consulta popular, también se puede hacer lo mismo con unas elecciones parlamentarias o presidenciales. Difícilmente puede considerarse legítimo un proceso de participación ciudadana en ausencia de los más básicos valores democráticos (aunque existan contadísimas excepciones, como el citado caso chileno).

\section{Conclusiones finales}

Dice el profesor Frank Ankersmit (2013) que "la democracia directa nunca podría fundar una nación"66; nuestra experiencia, sin embargo, nos dice todo lo contrario. ¿Cuántos Estados europeos modernos se constituyeron por Referéndum con posterioridad a la Segunda Guerra Mundial? Nos atrevemos a afirmar que, de hecho, la democracia directa es la forma más idónea de fundar una nación.

El Referéndum puede parecer un instrumento anticuado, excesivamente complejo y pesado para la sociedad moderna; desfasado en comparación con las modernas posibilidades de participación que ofrecen las nuevas tecnologías. Pero también es una de las instituciones con más tradición en nuestro constitucionalismo europeo, y la que ofrece las mayores garantías en cuanto a procedimiento y expresión de la voluntad ciudadana.

66. Ankersmit, Frank: "Representative Democracy”. Antiteses, vol, $6 n^{\circ} 12,2013$, p. 465.
Es cierto que el Referéndum, como instrumento de participación directa, responde a una lógica democrática distinta del sistema representativo, en la medida en que implica la manifestación directa y expresa de la voluntad ciudadana, en lugar de su delegación en la figura de un representante. Pero esto no implica necesariamente que ambos sistemas sean incompatibles: en cualquier caso, el conflicto puede venir dado porque el mandato referendario, por su carácter directo, tiene mayor fuerza imperativa. Incluso en países como Reino Unido, donde impera claramente el principio de soberanía parlamentaria, se ha recurrido al Referéndum para la solución de ciertas cuestiones políticas de gran relevancia, sin que esto haya implicado un cambio radical del modelo institucional.

No creemos que el Referéndum deba desaparecer de nuestro ordenamiento jurídico: en todo caso, debe adaptarse, modernizarse. Pensamos que las propuestas ofrecidas en este texto pueden ser un buen primer paso para integrar mejor el Referéndum en nuestro ordenamiento, mas, como siempre ocurre en democracia, la práctica y la teoría son completamente distintas. No pretendemos dar la solución a todos los problemas. La democracia, como ya hemos dicho tantas veces, es un aprendizaje. Eventualmente llegarán momentos de crisis, las instituciones fallarán, y las herramientas de las que disponemos parecerán insuficientes. Esto no puede evitarse, sino todo lo contrario, ha de ser afrontado con entereza por parte tanto del mundo político como, más aún, del jurídico. Un Derecho exitoso es aquel que logra adaptarse a las coyunturas, aquel que muestra capacidad de evolución. Cualquier otra cosa significa un estancamiento, y la norma estancada es una norma muerta. 


\section{Bibliografía}

\section{Marco jurídico}

El presente estudio se ha elaborado con referencia a las disposiciones y la jurisprudencia reseñadas en este apartado. En aquellos casos en donde haya sido necesario referenciar normativa extrajera, nos atenemos a las traducciones propuestas por los autores de los textos citados correspondientes.

\section{Normativa empleada}

Constitución Española de 1978.

Ley Orgánica 2/1980, de 18 de enero, sobre regulación de las distintas modalidades de referéndum.

Ley 7/1985, de 2 de abril, reguladora de las Bases del Régimen Local.

Ley Orgánica 4/2006, de 26 de mayo, de modificación de la Ley Orgánica 3/1984, de 26 de marzo, reguladora de la Iniciativa Legislativa Popular.

Ley Orgánica 2/1979, de 3 de octubre, del Tribunal Constitucional.

\section{Jurisprudencia}

Sentencia del Tribunal Constitucional $n^{\circ}$ 119/1995, de 17 de julio.

Sentencia del Tribunal Constitucional $n^{\circ}$ 103/2008, de 11 de septiembre.

Sentencia del Tribunal Constitucional $n^{\circ}$ 31/2010, de 28 de junio.

\section{Libros y tesis doctorales}

Aguiar de Luque, Luis: "Democracia directa y Estado constitucional". Edersa, Madrid, 1977.
Aguiar de Luque, Luis (colaborador): Trujillo, Gumersindo; López Guerra, Luis; y González-Trevijano, Pedro (directores): "Democracia directa e instituciones de democracia directa en el ordenamiento constitucional español". La experiencia constitucional, Centro de Estudios Políticos y Constitucionales, Madrid, 2000.

Cuesta López, Víctor Manuel: "Participación directa e iniciativa legislativa del ciudadano en democracia constitucional". Tesis doctoral, Universidad de las Palmas de Gran Canaria, 2007.

De Esteban, Jorge (coautor): "El régimen constitucional español, volumen 1”, Labor Universitaria, Barcelona, 1980.

\section{Artículos}

Ankersmit, Frank: "Representative Democracy". Antíteses, vol, $6 n^{\circ}$ 12, 2013, pp. 456-467.

Cascajo Castro, José Luis, García, Eloy, Oliver Araujo, Joan, \& Torres Muro, Ignacio: "Encuesta sobre el referéndum". UNED, Teoría y Realidad Constitucional, $n^{\circ} 30,2012$, pp. 11-56.

Koller, Heinrich, \& Biagnni, Giovanni: "La nueva Constitución Federal Suiza. Una visión General de las novedades y los aspectos más destacados". Teoría y Realidad constitucional, $\mathrm{n}^{\circ} 10-11,2002$, pp. 611-634.

Linde Paniagua, Enrique y Herrero Lera, Miguel: "Comentario a la Ley Orgánica de Modalidades de Referéndum". Revista de Derecho Político, n6, UNED, pp. 83-105. López González, José Luis: “El referéndum nacional consultivo sobre decisiones políticas de especial trascendencia". Cuadernos Constitucionales de la Cátedra Fadrique Furió Ceriol, n³8/39, Valencia, 2002, pp. 207-218. 
Martín Núñez, Esther: “El referéndum y las consultas populares en las Comunidades Autónomas y municipios". Revista Vasca de administración pública, n94, 2012, pp. 95-131.

Martino, Antonio A.: "Brexit". POSTData: Revista de Reflexión y Análisis Político, vol. 21 n², 2016, pp. 565-575.

Oliver Araujo, Joan: "El referéndum en el sistema constitucional español". Revista de Derecho Político, n²9, 1989, pp. 95148.

Olivietti, Marco: "Los refrendos en serio: la experiencia italiana". Traducción de Francisco M. Ruiz-Risueño Montoya para la Universidad Autónoma de Madrid.

Pérez Luño, Antonio Enrique. “Democracia directa y democracia representativa en el sistema constitucional español": Anuario de Filosofía del Derecho, n²0, 2003, pp. 63-82.

Presno Linera, Miguel Ángel (coordinador): "Partidos políticos y movimientos ciudadanos en la sociedad del riesgo y la desconfianza". Fundamentos: Cuadernos monográficos de teoría del estado, derecho público e historia constitucional, n8, 2014, 213-252.

Rubio Llorente, Francisco: "El bloque de constitucionalidad". Revista Española de Derecho Constitucional, n²7, 1989, pp. 9-37.

Sáenz Royo, Eva: “La regulación y la práctica del referéndum en Suiza: un análisis desde las críticas a la institución del referéndum." Revista de Estudios Políticos, $\mathrm{n}^{\circ}$ 171, 2016, pp. 71-104.

Soto Barrientos, Francisco: "La democracia como forma de Estado: Análisis de los mecanismos de participación directa en la Constitución Suiza". Estudios Constitucionales, vol. 10, n¹, 2012, pp. 373-402. 